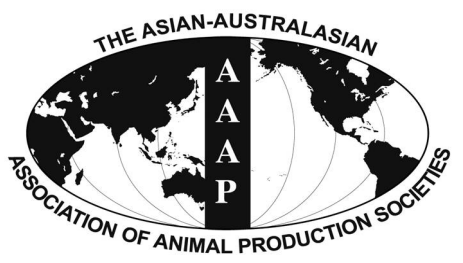

Open Access

Asian Australas. J. Anim. Sci.

Vol. 28, No. 10 : 1394-1406 October 2015

http://dx.doi.org/10.5713/ajas.14.0860

Www.ajas.info

pISSN 1011-2367 elSSN 1976-5517

\title{
Novel Nucleotide Variations, Haplotypes Structure and Associations with Growth Related Traits of Goat AT Motif-Binding Factor (ATBF1) Gene
}

\author{
Xiaoyan Zhang, Xianfeng Wu, Wenchao Jia ${ }^{1}$, Chuanying Pan, Xiangcheng $\mathrm{Li}^{2}$, \\ Chuzhao Lei, Hong Chen, and Xianyong Lan* \\ College of Animal Science and Technology, Northwest A\&F University, \\ Shaanxi Key Laboratory of Molecular Biology for Agriculture, Yangling, Shaanxi 712100, China
}

\begin{abstract}
The AT motif-binding factor (ATBF1) not only interacts with protein inhibitor of activated signal transducer and activator of transcription 3 (STAT3) (PIAS3) to suppress STAT3 signaling regulating embryo early development and cell differentiation, but is required for early activation of the pituitary specific transcription factor 1 (Pitl) gene (also known as POU1F1) critically affecting mammalian growth and development. The goal of this study was to detect novel nucleotide variations and haplotypes structure of the $A T B F 1$ gene, as well as to test their associations with growth-related traits in goats. Herein, a total of seven novel single nucleotide polymorphisms (SNPs) (SNP 1-7) within this gene were found in two well-known Chinese native goat breeds. Haplotypes structure analysis demonstrated that there were four haplotypes in Hainan black goat while seventeen haplotypes in Xinong Saanen dairy goat, and both breeds only shared one haplotype (hap1). Association testing revealed that the SNP2, SNP5, SNP6, and SNP7 loci were also found to significantly associate with growth-related traits in goats, respectively. Moreover, one diplotype in Xinong Saanen dairy goats significantly linked to growth related traits. These preliminary findings not only would extend the spectrum of genetic variations of the goat $A T B F 1$ gene, but also would contribute to implementing marker-assisted selection in genetics and breeding in goats. (Key Words: $A T B F 1$ Gene, Single Nucleotide Polymorphisms, Haplotypes, Growth-related Traits, Association)
\end{abstract}

\section{INTRODUCTION}

As the global economy is rapidly expanding, the demand for goat products is increasing in numerous developed and developing countries, such as China, India and South Africa. However, these goat products are experiencing serious shortage in those countries. Therefore, the question of how to improve goat growth and development has aroused interests in goat selection and breeding (Choudhary et al., 2007). The growth-related traits (e.g. body weight, body length, body height) are controlled

\footnotetext{
* Corresponding Author: Xianyong Lan. Tel: +86-29-87092102, Fax: +86-29-87092164, E-mail: lanxianyong79@nwsuaf.edu.cn ${ }^{1}$ College of Life Sciences, Northwest A\&F University, Yangling, Shaanxi 712100, China.

${ }^{2}$ Institute of Beijing Animal Science and Veterinary, Chinese Academy of Agricultural Science, Beijing 100194, China.

Submitted Nov. 6, 2014; Revised Mar. 11, 2015; Accepted Apr. 1, 2015
}

by multiple genes, so it is difficult to rapidly improve growth traits using traditional methods. Consequently, an effective DNA marker-assisted selection (MAS) would speed up the development and improvement goat products. Besides, it is more realistic to focus on some important genes and explore their nucleotide variations with growthrelated traits. Thereby, identifying, mapping, and analyzing novel nucleotide variations of the candidate genes and detecting their associations with economic traits are required for an effective MAS system.

AT motif-binding factor (ATBF1, also known as Zinc finger homeobox 3 [ZFHX3]) gene was firstly isolated as an AT (adenine and thymine)-binding factor of human $\alpha$ fetoprotein (AFP) and was mapped in human Chr.16q22.3q23.1 (Morinaga et al., 1991). Human ATBF1 is found to have two different transcripts: ATBF1-A and ATBF1-B. Function experiments show that ATBF1-A inhibits the enhancer of AFP and induces cell differentiation and death, 
while ATBF1-B promotes AFP expression by activating its enhancer (Ninomiya et al., 2002; Nojiri et al., 2004; Jung et al., 2005; Sun et al., 2007; Cleton-Jansen et al., 2008; Kai et al., 2008). From the available studies, ATBF1 is responsible for suppressing AFP transcription by binding with its enhancer competing with hepatocyte nuclear factor-1 (HNF-1) (Yasuda et al., 1994), thereby it plays an important role in cell differentiation and death (Ishii et al., 2003; Jung et al., 2011; Perea et al., 2013), tumour genesis (Sun et al., 2012; Sun et al., 2014), atrial fibrillation and embryonic development (Benjamin et al., 2009; Gudbjartsson et al., 2009; Perea et al., 2013). Furthermore, ATBF1 interacts with Smads to regulate thyroid-stimulating hormone beta (TSH- $\beta$ ) signaling pathway (Massagué, 2005; Moustakas et al., 2009; Massagué et al., 2012), thus it represses AFP expression (Sakata et al., 2014). Besides, ATBF1 regulates estrogen receptor signaling, functioning mammary gland (Li et al., 2012) and as well as in progesterone receptors signaling signaling (Li et al., 2013).

To date, ATBF1 is described as the biggest antitranscription factor for regulating expression of many critical genes, such as signal transducer and activator of transcription 3 (STAT3), pituitary specific transcription factor 1 (Pit1) (also known as POU1F1) and prophet of Pit1 (PROP1) genes. ATBF1 interacts with protein inhibitor of activated STAT3 (PIAS3) by forming ATBF1-PIAS3 complex and combining with active STAT3, thereby inhibiting expression of proliferative genes by reducing STAT3- DNA binding activity (Nojiri et al., 2004; Nishio et al., 2012; Jiang et al., 2014). Importantly, ATBF1 not only activates expression of Pit 1 gene though interacting with Pit1 enhancer (Qi et al., 2008), but also potentially synergizes with PROP1 that can bind to the enhancer of Pit1 gene and regulate the expression levels of growth hormone, prolactin, and TSH- $\beta$ (Carvalho et al., 2006; Davis et al., 2010; Araujo et al., 2013). STAT3, Pit1, and PROP1 genes play an important role in embryo early development and cell differentiation (Zhong et al., 1994; Schindler et al., 1995; Darnell, 1997; Heinrich et al., 1998; Shuai et al., 1999; Kamohara et al., 2000; Fang et al., 2012; Godi et al., 2012; Akcay et al., 2013; Pan et al., 2013; Navardauskaite et al., 2014), so ATBF1 gene was hypothesized to produce important effects on early development and cell differentiation, thus it would affect the grow traits in animals.

To date, few studies about the nucleotide variations of goat $A T B F 1$ gene and its effects on growth traits have been reported. To improve understanding of goat $A T B F 1$ gene, this work firstly explored the novel nucleotide variations, haplotypes structure of goat $A T B F 1$ gene, and analyzed its associations with growth related traits. These findings would not only extend the spectrum of genetic variations of the goat $A T B F 1$ gene, but also would contribute to implementing MAS in genetics and breeding in goats.

\section{MATERIALS AND METHODS}

\section{Animals and data collection}

In this study, a total of 707 goats from two well-known Chinese native goat breeds (Hainan Black goats $[\mathrm{HNBG}]=$ 284; Xinong Saanen dairy goats $[\mathrm{XNSN}] \mathrm{n}=423$ ) were used. All selected individuals were healthy and unrelated. The HNBG goats were 2 to 3 years old and reared in native breeding farms, in Zanzhou County, Hainan province, China. All XNSN individuals were 2 to 6 years old, among which $21.3 \%, 50.8 \%, 8.9 \%, 12.7 \%$, and $6.3 \%$ were 2 years old, 3 years old, 4 years old, 5 years old, and 6 years old, respectively. The XNSN goats were reared on Chinese native dairy goat breeding farm in Qianyang County, Shaanxi Province, China (Zhao et al., 2013).

Body measurement traits for all selected individuals were measured, including body weight (BW), body height, body length (BL), chest circumference (ChC), chest depth, chest width, hucklebone width (HuW), hip width, and cannon circumference $(\mathrm{CaC})$, according to the method of Gilbert et al. (1993). Consequently, body length index (BLI), chest circumference index (ChCI), cannon circumference index $(\mathrm{CaCl})$, hucklebone width index (HuWI) and trunk index (TI) were also calculated on the basis of our reported description (Fang et al., 2010).

\section{DNA isolation and DNA pool construction}

Extraction of DNA samples from ear tissues and blood leukocytes (Sambrock et al., 2001; Green et al., 2012) were diluted to working concentration $(50 \mathrm{ng} / \mu \mathrm{L})$ according to our previous report (Lan et al., 2013). A total of 50 DNA samples from two breeds were randomly selected to construct DNA pools, which were used as templates for polymerase chain reaction (PCR) amplification to explore SNPs of $A T B F 1$ gene.

\section{Primers design and DNA sequencing}

The 5' UTR, exons, introns and 3' UTR regions of the goat $A T B F 1$ gene were amplified from the constructed DNA pools. Fourteen pairs of primers were designed to amplify the goat $A T B F 1$ gene using Primer Premier Software (version 5.0) based on the sheep ATBF1 gene sequence (GenBank Accession No. NC_019471) as the goat was not available (Table 1). PCR reactions were performed in $25 \mu \mathrm{L}$ volume containing $50 \mathrm{ng}$ genomic DNA, $0.5 \mu \mathrm{M}$ of each primer, $1 \times$ Buffer (including $1.5 \mathrm{mM} \mathrm{MgCl} 2,200 \mu \mathrm{M}$ dNTPs and 0.625 units of Taq DNA polymerase [MBI, Vilnius, Lithuania]). The Touch-Down PCR protocol was as follows: denatured at $95^{\circ} \mathrm{C}$ for $5 \mathrm{~min}$, followed by 35 cycles of $94^{\circ} \mathrm{C}$ for $30 \mathrm{~s}, 68^{\circ} \mathrm{C}$ to $51^{\circ} \mathrm{C}$ for $30 \mathrm{~s}$, and $72^{\circ} \mathrm{C}$ for $2 \mathrm{~min}$, finally extended at $72^{\circ} \mathrm{C}$ for $10 \mathrm{~min}$. Then to sequence 
Table 1. PCR primer sequences of the goat $A T B F 1$ gene for amplification

\begin{tabular}{|c|c|c|c|c|}
\hline Loci & Primer sequences $\left(5^{\prime} \rightarrow 3^{\prime}\right)$ & $\begin{array}{l}\mathrm{Tm} \\
\left({ }^{\circ} \mathrm{C}\right)\end{array}$ & $\begin{array}{c}\text { Sizes } \\
\text { (bp) }\end{array}$ & Detection methods \\
\hline$\overline{\mathrm{P} 1}$ & $\begin{array}{l}\text { Forward: AAGGACAATGGGTGCGGTAT (nt24226-24245) } \\
\text { Reverse: AGCGGTGGAAACTAAAGGGA (nt25435-25454) }\end{array}$ & 60 & 1,229 & Pool DNA sequencing \\
\hline P2 (SNP1) & $\begin{array}{l}\text { Forward: CTTTCCACATAGCCTCATCCTT(nt24979-25000) } \\
\text { Reverse: TTTATTGGCACTTTCATCAGCA (nt26159-26180) }\end{array}$ & 62.5 & 1,202 & $\begin{array}{l}\text { TaqI PCR-RFLP } \\
\begin{array}{l}(\mathrm{AA}=824+159+112+105 \mathrm{bp} \\
\mathrm{AG}=824+517+307+159+112+105 \mathrm{bp} \\
\mathrm{GG}=517+307+159+112+105+\mathrm{bp})\end{array}\end{array}$ \\
\hline $\begin{array}{l}\text { P2 } \\
\text { (mis-match-SNP2) }\end{array}$ & $\begin{array}{l}\text { Forward: CAAGAAGTGGGTGATCCAGACTGTTTC }{ }^{1} \text { वc } \\
\text { (nt25718-25747) } \\
\text { Reverse: TCGCACCATCAAAGACAAC(nt26064-26082) }\end{array}$ & 55 & & $\begin{array}{l}\text { MspI PCR-RFLP } \\
(\mathrm{AA}=365 \mathrm{bp} \\
\mathrm{AG}=365+337+28 \mathrm{bp} \\
\mathrm{GG}=337+28 \mathrm{bp})\end{array}$ \\
\hline P3 & $\begin{array}{l}\text { Forward: TGCTGATGAAAGTGCCAATA (nt26159-26178) } \\
\text { Reverse: TTGACGAAACCCGAAAGTAG (nt27525-27564) }\end{array}$ & 62.5 & 1,406 & Pool DNA sequencing \\
\hline $\begin{array}{l}\text { P3 } \\
\text { (mis-match-SNP3) }\end{array}$ & $\begin{array}{l}\text { Forward: ATGCGACACGGTCCTGG(nt26321-26337) } \\
\text { Reverse: GGATGCGCAGGTTCCGGGCCACGTTGG A } \mathrm{ACT} \\
\text { (nt26903-26932) }\end{array}$ & 61.3 & & $\begin{array}{l}\text { HinfI PCR-RFLP } \\
(\mathrm{AA}=533 \mathrm{bp} \\
\mathrm{AG}=533+503+30 \mathrm{bp} \\
\mathrm{GG}=503+30 \mathrm{bp})\end{array}$ \\
\hline P4 (SNP4) & $\begin{array}{ll}\text { Forward: GTGTCAGGTGTCCCATAGCC } & \text { (nt31489-31508): } \\
\text { Reverse: AATGCCAGTCCCTCCAGTTA } & \text { (nt32615-32634) }\end{array}$ & 62.8 & 1,146 & $\begin{array}{l}\text { Aval PCR-RFLP } \\
(\mathrm{CC}=1082+71 \mathrm{bp} \\
\mathrm{CG}=1082+574+508+71 \mathrm{bp} \\
\mathrm{GG}=574+508+71 \mathrm{bp})\end{array}$ \\
\hline $\begin{array}{l}\text { P4 } \\
\text { (mis-match-SNP5) }\end{array}$ & $\begin{array}{l}\text { Forward: AGCAGTGGATAGCACCTTG(nt31888-31905) } \\
\text { Reverse: GCATGTCTAGGGGGATTTCACCGCCCAC' } \mathrm{CG} \\
\text { (nt32030-32059) }\end{array}$ & 58.3 & 172 & $\begin{array}{l}\text { ScaII PCR-RFLP } \\
\begin{array}{l}(\mathrm{AA}=172 \mathrm{bp} \\
\mathrm{AG}=172+140+32 \mathrm{bp} \\
\mathrm{GG}=140+32 \mathrm{bp})\end{array}\end{array}$ \\
\hline P5 & $\begin{array}{l}\text { Forward: ATGGACGATGCACGAACC } \quad(n t 88882-88899) \\
\text { Reverse: GATCTGAACCCAAAGACTGAA (nt89740-89760) }\end{array}$ & 59.5 & 879 & Pool DNA sequencing \\
\hline P6 & $\begin{array}{l}\text { Forward: GCTCAGGCACCACGAAG (nt144646-144662) } \\
\text { Reverse: CAGGACACCAGGGATACAAA (nt145712-145731) }\end{array}$ & 59.5 & 1,086 & Pool DNA sequencing \\
\hline P7 (SNP6,SNP7) & $\begin{array}{l}\text { Forward: GACTCTTACCCAGCACGTACCCT(nt162942-162964) } \\
\text { Reverse: TAACAGAAACCCACCATCCACAA(nt164391-164413) }\end{array}$ & 55.9 & 1,472 & $\begin{array}{l}\text { PstI PCR-RFLP } \\
(\mathrm{CC}=1,260+212 \mathrm{bp} ; \\
\mathrm{CG}=1,260+757+503+212 \mathrm{bp} ; \\
\mathrm{GG}=757+503+212 \mathrm{bp}) \mathrm{MspI} \text { PCR-RFLP } \\
(\mathrm{AA}=1064+203+135+70 \mathrm{bp} ; \\
\mathrm{AG}=1064+898+203+166+135+70 \mathrm{bp} ; \\
\mathrm{GG}=898+203+166+135+70 \mathrm{bp})\end{array}$ \\
\hline P8 & $\begin{array}{l}\text { Forward: TGTTAGTTCAGGGTCAGTTC(nt172005-172022) } \\
\text { Reverse: ATGGAGACATCATAAGGGAG(nt173796-173815) }\end{array}$ & 58 & 1,811 & Pool DNA sequencing \\
\hline P9 & $\begin{array}{l}\text { Forward: TCCTCCCTTATGATGTCTCCA(nt173794-173814) } \\
\text { Reverse: GGTAGTTCAAGTTGCTCGTTC(nt177384-177404) }\end{array}$ & 50 & 3,611 & Pool DNA sSequencing \\
\hline P10 & $\begin{array}{l}\text { Forward: GTACCGCGAGCACTACGACA(nt176420-176439): } \\
\text { Reverse: GGACCTCAGGGAACAGCAAA(nt180298-180317) }\end{array}$ & 64 & 3,898 & Pool DNA sequencing \\
\hline P11 & $\begin{array}{l}\text { Forward: AACCGTCCTCAGCATCGC (nt184007-184024) } \\
\text { Reverse: CGTGTCAGACTCCTCCGAAT (nt185402-185421) }\end{array}$ & 60 & 1,415 & Pool DNA sequencing \\
\hline
\end{tabular}

PCR, polymerase chain reaction; ATBF1, AT motif-binding factor 1; SNP, single nucleotide polymorphism; TaqI, Thermus aquaticus YT-1; MspI, Moraxella species; HinfI, Haemophilus influenzae Rf; AvaI, Bacillus megaterium T110; ScaII, Streptomyces achromogenes; PstI, pancreatic secretory trypsin inhibitor; PCR-RFLP, PCR- restriction fragment length polymorphism.

${ }^{1} \mathrm{~N}$ showed a mismatch of forward or reverse primer for creating a restriction site.

accurately, the products were sequenced only when they had a single objective band of each pair of primers.

\section{Genotyping using PCR-based amplification-created restriction site-restriction fragment length polymorphism (PCR-ACRS-RFLP) and PCR-RFLP}

The primers were selected to amplify and genotype the variants of goat $A T B F 1$ gene only if mutations were found after DNA pool sequencing and Blastn analyses. In this work, seven novel SNPs were detected, namely
NC_019471:g.25504G $>$ A (SNP1), g.25748G $>$ A (SNP2), g.26902 A $>$ G (SNP3), g.32001 C >G (SNP4), g.32029 A $>$ G (SNP5), g.163442 C $>\mathrm{G}$ (SNP6), g.163517A $>\mathrm{G}$ (SNP7).

In order to detect these SNPs, the PCR-restriction fragment length polymorphism (RFLP) and PCRamplification-created restriction site (ACRS)-RFLP were carried out. i) For the NC_019471:g.25504 G>A (SNP1) locus, the endonuclease Thermus aquaticus YT-1 (TaqI) (TCGA) was used to genotype the SNP of g.25504 G, not g.25504 A. ii) For the NC 019471: g.25748 G>A (SNP2) 
locus, created restriction endonuclease Moraxella species (Msp1) site (CCGG) was formed when the forward primer actual nucleotide "T" was induced to "C" at $\mathrm{NC} 019471$ : g.25746 locus. Thus the Msp 1 could recognize the SNP of g. $25748 \mathrm{G}$ with induced point mutation g.25746 C, not with g.25746 T. iii) For the NC_019471: g.26902 A>G (SNP3) locus, new restriction endonuclease Haemophilus influenzae Rf (HinfI) site (GANTC) was established by changing the reverse primer actual nucleotide " $\mathrm{A}$ " to " $\mathrm{T}$ " at NC_019471: g.26905 locus. Then the SNP of g.26902 G with induced point mutation g.26905 T could be genotyped by HinfI PCR -ACRS-RFLP, rather than g.26905 A. iv) For the NC_019471: g.32001 C $>\mathrm{G}$ (SNP4) locus, the endonuclease Bacillus megaterium T110 (AvaI) site (CYCGRG) was used to genotype the allele of g. $32001 \mathrm{G}$, not the g. 32001 C. v) Since the NC 019471: g.32029 A>G (SNP5) also could not be genotyped by the natural restriction or economic restriction endonuclease, the other reverse primer was designed to form new restriction endonuclease Streptomyces achromogenes (ScaII) (CCGCGG) point. The actual nucleotide "A" was induced into "G" at the NC_019471: g.32031, so the Streptomyces achromogenes (ScaII) could genotype the SNP of g.32029 G with induced point mutation g.32031G, not with g.32031 A. vi) For the NC_019471: g.163442 C >G (SNP6) locus, the endonuclease pancreatic secretory trypsin inhibitor (PstI) (CTGCAG) was used to genotype the SNP of $\mathrm{g}$. $163442 \mathrm{G}$, not g. 163442 C. vii) For the NC_019471: g.163517A $>\mathrm{G}$ (SNP7) locus, the endonuclease MspI (CCGG) was used to genotype the SNP of g. g.163517 G, not g. g. $163517 \mathrm{~A}$.

For the above loci, the $8 \mu \mathrm{L}$ PCR products were digested with $3 \mathrm{U} T a q \mathrm{I}, M s p \mathrm{I}, \operatorname{Hinf\mathrm {I}}, A v a \mathrm{I}$, ScaII, PstI, MspI, respectively, for $12 \mathrm{~h}$ at $37^{\circ} \mathrm{C}$ except TaqI and HinfI, at $65^{\circ} \mathrm{C}$. The digested products were detected by electrophoresis of $1.5 \%$ to $3.5 \%$ agarose gel stained with ethidium bromide.

\section{Statistical analysis}

Genotypic frequencies, allelic frequencies and HardyWeinberg equilibrium (HWE) were analyzed by the SHEsis program (http://analysis.bio-x.cn) (Li et al., 2009), as well as linkage disequilibrium (LD) structure and haplotypes across seven SNPs loci in HNBG and XNSN breeds (Wang et al., 2013). According to PopGene version 1.3.1 (Yeh et al., 2000), population parameters, such as gene heterozygosity $(\mathrm{He})$, effective allele numbers $(\mathrm{Ne})$ and polymorphism information content (PIC) were calculated.

The associations of the genetic variations and growthrelated traits were calculated according to the general linear model by the SPSS software (version 18.0) (International Business Machines [IBM] Corporation, New York, USA) for Windows. Statistical testing was carried on the records of growth traits of HNBG and XNSN goats. The mixed statistical of the linear model analysis, not including the effects of farm, sex, season of birth (spring versus fall), age of dam and sire, which had no significant effects on the variation of traits in the mammal populations (Lan et al., 2007; Zhao et al., 2013). Therefore, the statistical linear model was: $Y_{i j k}=\mu+A_{i}+G_{j}+e_{i j k}$, where $Y_{i j k}$ is the observation of the body measurement traits, $\mu$ is the overall mean of each trait, $A_{i}$ is the fixed effect of age, $G_{j}$ is the fixed effect of genotype or combined genotype, and $\mathrm{e}_{\mathrm{ij} k}$ is the random residual error (He et al., 2014; Wang et al., 2014). Thus the fixed effect of genotypes and age was a major source of variation and the $\mathrm{p}$-value for the difference between the least squares means was less than 0.05. Diplotypes of combined haplotypes of SNPs with growth traits correlation analysis were carried out to explore the possible interactions between the SNPs. The model was similar to above model analysis, except that the interaction between two SNPs was treated as a fixed effect.

\section{RESULTS}

\section{Novel nucleotide variations within goat $A T B F 1$ gene}

After DNA sequencing and alignment analysis, seven SNPs loci were firstly found, namely, SNP1-7 (Figure 1). The SNP1-TaqI locus (25504 G>A) was located at exon 2 and mutated from $\mathrm{G}$ to $\mathrm{A}$, resulting in a missense mutation, CGA (372 R) to CAA (372 Q), which could be genotyped by the TaqI PCR-RFP method (Figure 2a). The SNP2-MspI locus $(25748 \mathrm{G}>\mathrm{A})$ was located at exon 2 and mutated from $\mathrm{G}$ to $\mathrm{A}$, resulting in a synonymous change, TCG (453 Ser) to TCA ( $453 \mathrm{Ser}$ ), which could be genotyped by the Msp I PCR-ACRS-RFP method (Figure 2b). The SNP3-HinfI locus $(26902 \mathrm{~A}>\mathrm{G})$ was located at exon3 and mutated from A to $\mathrm{G}$, resulting in a missense change, AAA ( $453 \mathrm{~K})$ to TCA (453 E), which could be genotyped by the HinfI PCRACRS-RFP method (Figure 2c).The SNP4-AvaI locus $(32001 \mathrm{C}>\mathrm{G}$ ) was located at intron 3 and mutated from $\mathrm{C}$ to G, which could be genotyped by the AvaI PCR-RFP method (Figure 2d). The SNP5-ScaII locus (32029 A>G) was located at intron 3 and mutated from A to G, which could be genotyped by the ScaII PCR-ACRS-RFP method (Figure 2e). The SNP6-PstI locus $(163442 \mathrm{C}>\mathrm{G})$ was located at exon 8 and mutated from $\mathrm{C}$ to $\mathrm{G}$, which could be genotyped by the PstI PCR-RFP method (Figure 2f). The SNP7-MspI locus $(163517 \mathrm{~A}>\mathrm{G})$ was located at intron 8 and mutated from A to G, which could be genotyped by the MspI PCRRFP method (Figure 2g).

\section{Frequencies of genotypes and alleles within goat $A T B F 1$ gene}

Statistics analysis showed that the frequencies of genotypes and main alleles are different at different SNP 

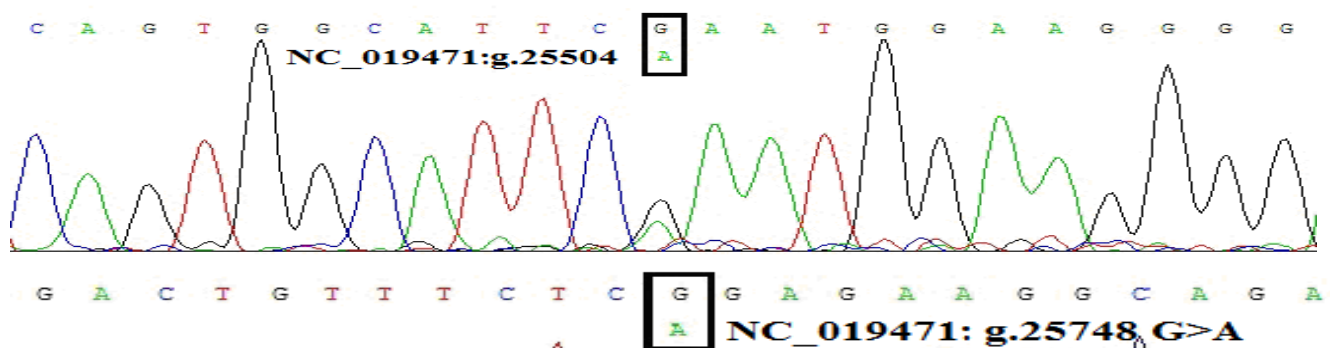

a. SNP1

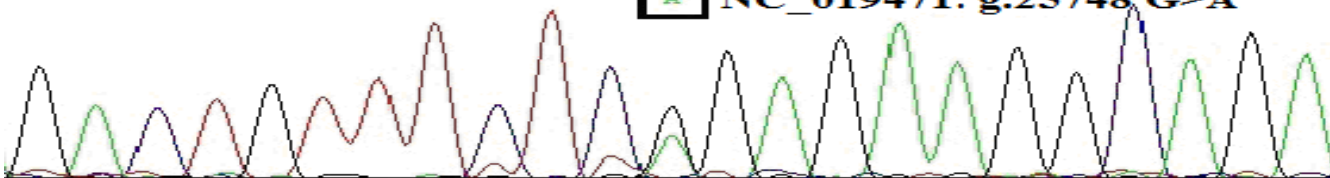

b. SNP2

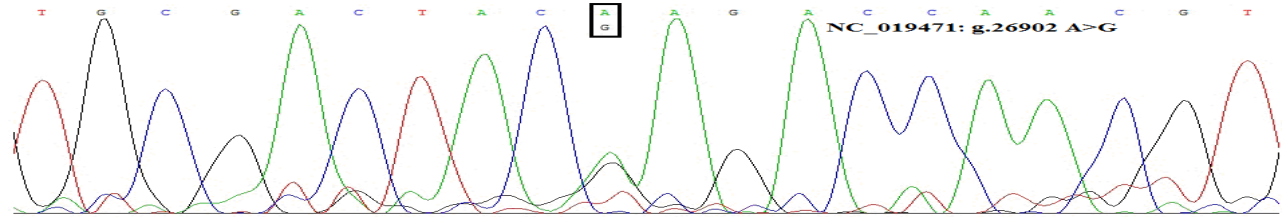

c. SNP3

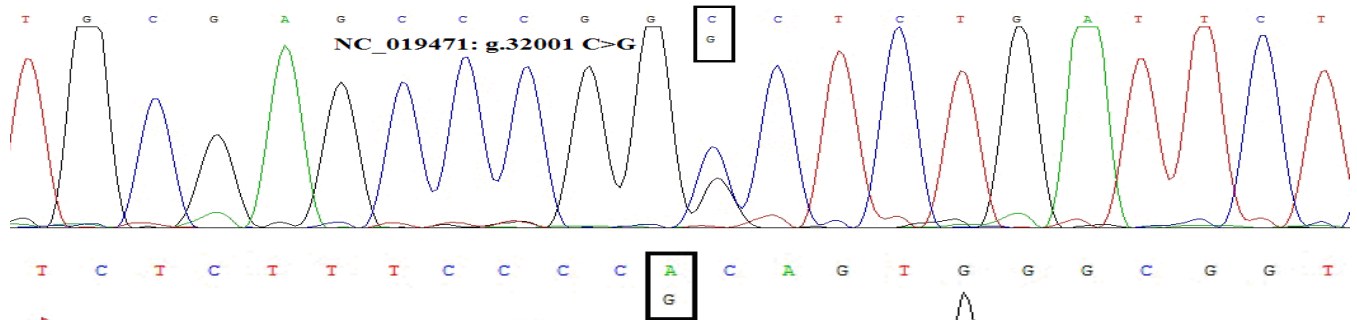

d. SNP4

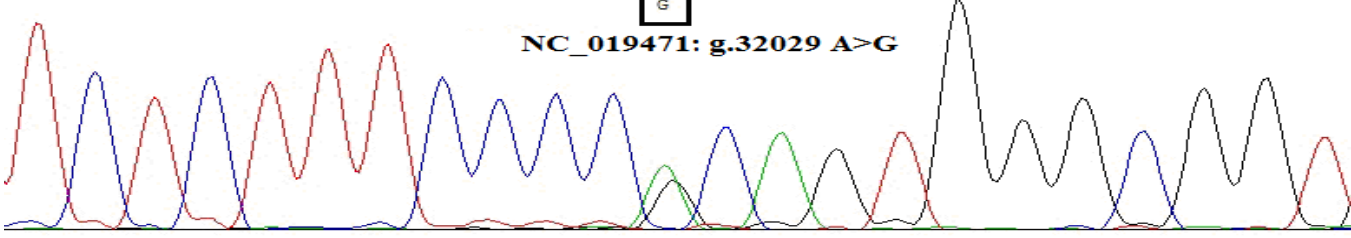

e. SNP5

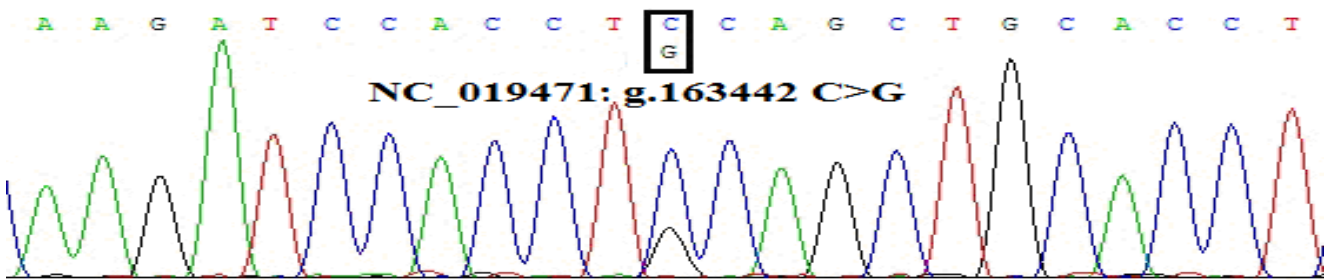

f. SNP6

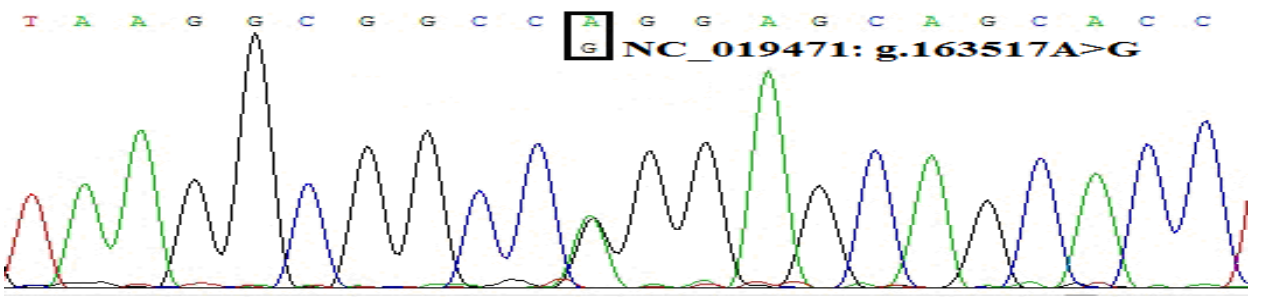

Figure 1. Sequence chromas of seven novel SNPs loci of the goat $A T B F 1$ gene. a to g represented the pooling sequence chromas of NC_019471:g.25504G >A (SNP1), g.25748G >A (SNP2), g.26902 A $>$ G (SNP3), g.32001 C >G (SNP4), g.32029 A $>$ G (SNP5), g.163442 $\mathrm{C}>\mathrm{G}$ (SNP6), g.163517A $>\mathrm{G}$ (SNP7), respectively. SNPs, single nucleotide polymorphisms; ATBF1, AT motif-binding factor 1.

loci in two goat breeds (Table 2). For example, only one genotype of SNP4-AvaI, SNP5-SacII, and SNP6-PstI was found in HNBG, but three genotypes were found in XNSN dairy goat. The frequencies of two alleles of each SNP locus in XNSN dairy goat, SNP4-AvaI and SNP5-SacII loci were approximately same except the SNP6-PstI locus. As shown in Table 2, the frequencies of the two alleles of SNP2-MspI were similar in both HNBG and XNSN dairy goats, as well as SNP7-MspI locus. The classification of PIC values demonstrated that all SNPs loci were medium genetic 


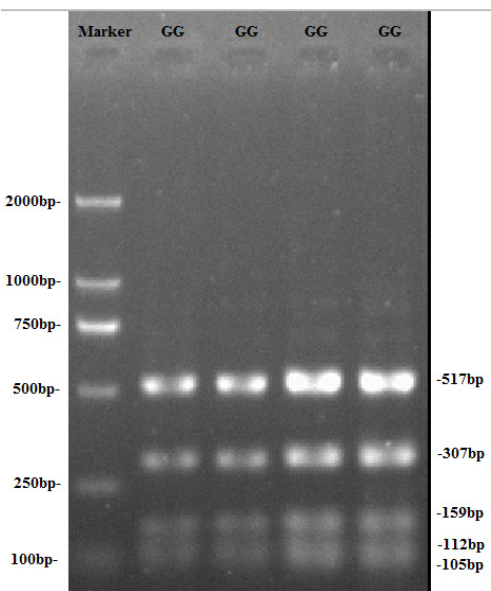

a. SNP1

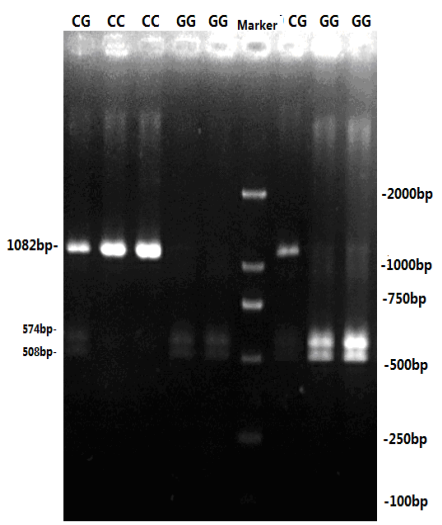

d. SNP4

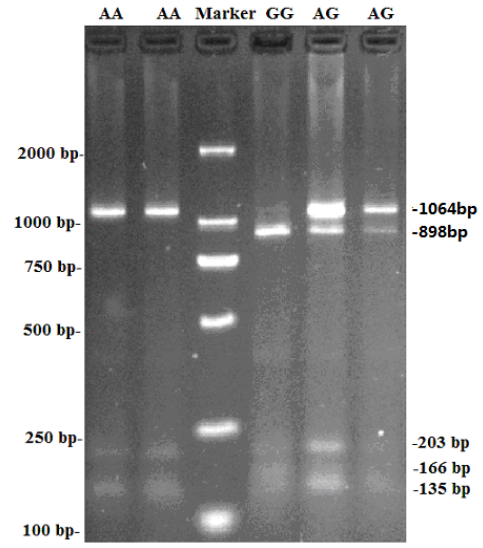

g. SNP1

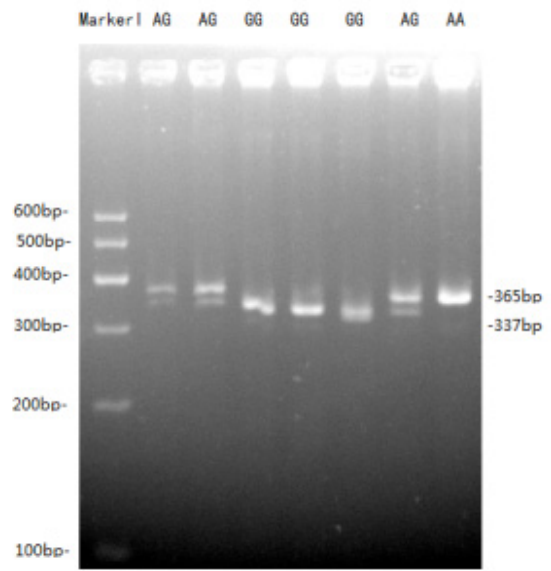

b. SNP2

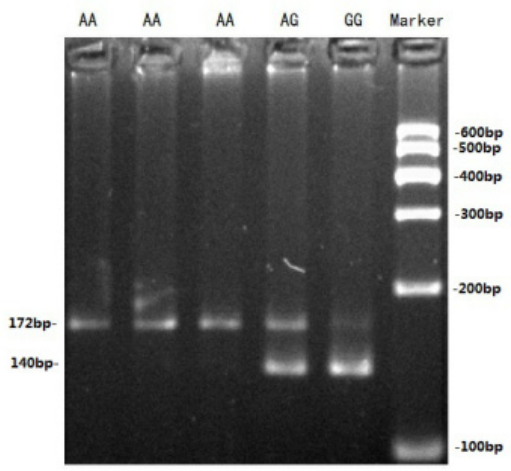

e. SNP2

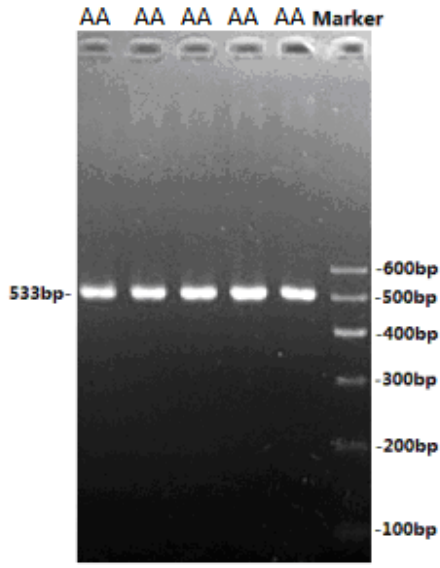

c. SNP3

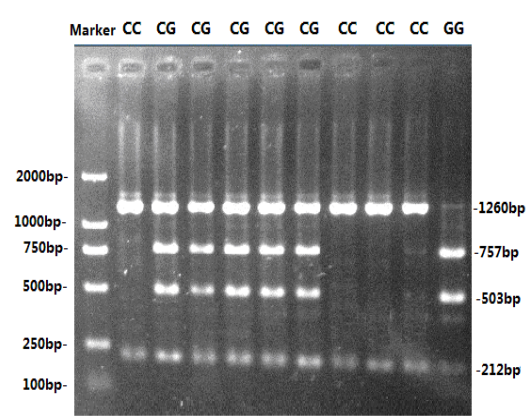

f. SNP3

Figure 2. Electrophoresis pattern of seven novel genetic variations of goat $A T B F 1$ gene. a to $g$ represented the electrophoresis pattern of the SNP1-7 loci, respectively. ATBF1, AT motif-binding factor 1; SNPs, single nucleotide polymorphisms.

diversity except those that had only one kind of genotype and most SNPs loci were at HWE except SNP2-MspI and SNP5-SacII loci in XNSN dairy goat and SNP7-MspI locus in HNBG.

\section{Haplotype structure and linkage disequilibrium analysis}

Four haplotypes were found in HNBG while seventeen haplotypes in XNSN dairy goat (Table 3 ). Only 1 haplotype (hap 1) was simultaneously found in both breeds, but the frequency was low $(8.5 \%)$. The frequency of the hap 4 (27.5\%) was highest in HNBG, and the hap 13 (14.1\%) was the highest in XNSN dairy goat.

The LD of seven SNPs in two populations was analyzed. As shown in Table 4 and Figure 3, the $D^{\prime}$ and $r^{2}$ values of 
Table 2. Genotypes, alleles, He, Ne, and PIC for the SNPs of the goat ATBF1 gene

\begin{tabular}{|c|c|c|c|c|c|c|c|c|c|c|}
\hline \multirow{3}{*}{$\begin{array}{l}\text { Breeds/ } \\
\text { loci }\end{array}$} & \multirow{3}{*}{$\begin{array}{c}\text { Sizes } \\
(\mathrm{N})\end{array}$} & \multirow{2}{*}{\multicolumn{3}{|c|}{ Genotype numbers and frequencies $(\%)$}} & \multirow{2}{*}{\multicolumn{2}{|c|}{$\begin{array}{c}\text { Allele } \\
\text { frequencies }(\%)\end{array}$}} & \multirow{3}{*}{$\begin{array}{c}\text { HWE } \\
\text { p values }\end{array}$} & \multicolumn{3}{|c|}{ Population parameters } \\
\hline & & & & & & & & \multirow[t]{2}{*}{$\mathrm{He}$} & \multirow[t]{2}{*}{$\mathrm{Ne}$} & \multirow[t]{2}{*}{ PIC } \\
\hline & & AA & $\mathrm{AG}$ & GG & A & G & & & & \\
\hline HNBG & 284 & 0 & 0 & $284(100)$ & 0 & 100 & $>0.05$ & 0 & 1 & 0 \\
\hline XNSN & 423 & 0 & 0 & $423(100)$ & 0 & 100 & $>0.05$ & 0 & 1 & 0 \\
\hline SNP2-MspI & & AA & $\mathrm{AG}$ & GG & A & G & & & & \\
\hline HNBG & 284 & $70(24.6)$ & $144(50.7)$ & $70(24.6)$ & 50 & 50 & $>0.05$ & 0.500 & 2.000 & 0.375 \\
\hline XNSN & 423 & $136(32.2)$ & $83(19.6)$ & $204(48.2)$ & 41.9 & 58.1 & $<0.01$ & 0.487 & 1.950 & 0.368 \\
\hline SNP3-HinfI & & AA & $\mathrm{AG}$ & GG & A & G & & & & \\
\hline HNBG & 284 & $284(100)$ & 0 & 0 & 100 & 0 & $>0.05$ & 0 & 1 & 0 \\
\hline XNSN & 423 & $423(100)$ & 0 & 0 & 100 & 0 & $>0.05$ & 0 & 1 & 0 \\
\hline SNP4-AvaI & & $\mathrm{CC}$ & $\mathrm{CG}$ & GG & $\mathrm{C}$ & G & & & & \\
\hline HNBG & 284 & $284(100)$ & 0 & 0 & 100 & 0 & $>0.05$ & 0 & 1 & 0 \\
\hline XNSN & 423 & $102(24.2)$ & $183(43.3)$ & $138(32.5)$ & 45.8 & 54.2 & $<0.05$ & 0.496 & 1.986 & 0.373 \\
\hline SNP5-SacII & & AA & $\mathrm{AG}$ & GG & A & G & & & & \\
\hline HNBG & 284 & $284(100)$ & 0 & 0 & 100 & 0 & $>0.05$ & 0 & 1 & 0 \\
\hline XNSN & 423 & $171(40.4)$ & $153(36.2)$ & $99(23.4)$ & 58.5 & 41.5 & $<0.01$ & 0.492 & 1.968 & 0.371 \\
\hline SNP6-PstI & & $\mathrm{CC}$ & $\mathrm{CG}$ & GG & $\mathrm{C}$ & G & & & & \\
\hline HNBG & 284 & $283(99.6)$ & $1(0.4)$ & 0 & 99.8 & 0.2 & $>0.05$ & 0.500 & 2.000 & 0.375 \\
\hline XNSN & 423 & $263(62.2)$ & $140(33.1)$ & $20(4.7)$ & 78.6 & 21.4 & $>0.05$ & 0.460 & 1.851 & 0.354 \\
\hline SNP7-MspI & & AA & AG & GG & A & G & & & & \\
\hline HNBG & 284 & $72(25.4)$ & $102(35.9)$ & $110(38.7)$ & 43.3 & 56.7 & $<0.01$ & 0.491 & 1.965 & 0.370 \\
\hline XNSN & 423 & $137(32.5)$ & $188(44.4)$ & $98(23.1)$ & 54.7 & 45.3 & $>0.05$ & 0.496 & 1.983 & 0.373 \\
\hline
\end{tabular}

He, gene heterozygosity; Ne, effective allele numbers; PIC, polymorphism information content; SNPs, single nucleotide polymorphisms; ATBF1, AT motif-binding factor 1; HWE, Hardy-Weinberg equilibrium; HNBG, Hainan Black goat; XNSN, Xinong Saanen dairy goat.

HNBG were very low (approximately zero), except the D' of XNSN were very low as well as the D' values, except the values $(0.861)$ and $r^{2}$ values (0.02) between SNP6 and D' values between SNP4 and SNP5 (0.670), SNP4 and SNP7 loci. As shown in Table 5 and Figure 4, the $r^{2}$ values SNP6 (0.574), SNP4 and SNP7 (0.642), SNP6 and SNP7

Table 3. Haplotype frequency within the $A T B F 1$ gene in goat breeds

\begin{tabular}{|c|c|c|c|}
\hline \multirow{2}{*}{ Different haplotypes } & \multirow{2}{*}{ SNP1-SNP2-SNP3-SNP4- SNP5-SNP6-SNP7 } & \multicolumn{2}{|c|}{ Haplotype frequency } \\
\hline & & HNBG & XNSN \\
\hline Hap1 & GAACACA & 0.225 & 0.085 \\
\hline Hap2 & GAACAC G & 0.272 & 0 \\
\hline Hap3 & G G A C A C A & 0.228 & 0 \\
\hline Hap4 & G G A C A C G & 0.275 & 0 \\
\hline Hap5 & GAACA G G & 0 & 0.015 \\
\hline Hap6 & G A A C G C A & 0 & 0.134 \\
\hline Hap7 & GAAGACA & 0 & 0.046 \\
\hline Hap8 & GAAG A C G & 0 & 0.020 \\
\hline Hap9 & GAA G A G G & 0 & 0.027 \\
\hline Hap10 & GAAG GCG & 0 & 0.139 \\
\hline Hap11 & GA A G G GA & 0 & 0.016 \\
\hline Hap12 & GAAGGGG & 0 & 0.077 \\
\hline Hap13 & G G A C A C A & 0 & 0.141 \\
\hline Hap14 & G G A C A C G & 0 & 0.027 \\
\hline Hap15 & G G A C A G G & 0 & 0.020 \\
\hline Hap16 & G G A C G C A & 0 & 0.019 \\
\hline Hap17 & G G A G A C A & 0 & 0.016 \\
\hline Hap18 & G G A G G C A & 0 & 0.058 \\
\hline Hap19 & G GA G G C G & 0 & 0.036 \\
\hline Hap20 & G GA G G G G & 0 & 0.124 \\
\hline
\end{tabular}

ATBF1, AT motif-binding factor 1; SNP, single nucleotide polymorphism; HNBG, Hainan Black goat; XNSN, Xinong Saanen dairy goat; Hap, haplotype. 
Table 4. $\mathrm{D}^{\prime}$ and $\mathrm{r}^{2}$ values of pairwise linkage disequilibrium of the $A T B F 1$ gene in HNBG goat

\begin{tabular}{|c|c|c|c|c|c|c|c|}
\hline HNBG-locus/ D' & SNP1 & SNP2 & SNP3 & SNP4 & SNP5 & SNP6 & SNP7 \\
\hline SNP1 & - & 0.00 & 0.00 & 0.00 & 0.00 & 0.00 & 0.00 \\
\hline SNP2 & - & - & 0.000 & 0.00 & 0.00 & 0.00 & 0.001 \\
\hline SNP3 & - & - & - & 0.00 & 0.00 & 0.00 & 0.00 \\
\hline SNP4 & - & - & - & - & 0.00 & 0.00 & 0.00 \\
\hline SNP5 & - & - & - & - & - & 0.00 & 0.00 \\
\hline SNP6 & - & - & - & - & - & - & 0.861 \\
\hline SNP7 & - & - & - & - & - & - & - \\
\hline \multicolumn{8}{|l|}{ HNBG-locus $/ \mathrm{r}^{2}$} \\
\hline SNP1 & - & 0.00 & 0.00 & 0.000 & 0.000 & 0.00 & 0.00 \\
\hline SNP2 & - & - & 0.000 & 0.000 & 0.000 & 0.00 & 0.00 \\
\hline SNP3 & - & - & - & 0.000 & 0.000 & 0.00 & 0.00 \\
\hline SNP4 & - & - & - & - & 0.000 & 0.00 & 0.00 \\
\hline SNP5 & - & - & - & - & - & 0.00 & 0.00 \\
\hline SNP6 & - & - & - & - & - & - & 0.02 \\
\hline SNP7 & - & - & - & - & - & - & - \\
\hline
\end{tabular}

ATBF1, AT motif-binding factor 1; HNBG, Hainan Black goat; SNP, single nucleotide polymorphism.

(0.737).

Relationships between the genetic variations and related-growth traits

The associations of the genetic variations with growth related traits except SNP1 and SNP3 loci were determined (Table 6). In the SNP2-MspI locus, the genotype of AG had demonstrated significantly superior $\mathrm{HuWI}$ traits than genotype GG in HNBG, while genotype GG was found to have significantly superior $\mathrm{BL}, \mathrm{ChC}$, and $\mathrm{ChCI}$ traits when compared with genotype AA, as well as genotype GG and AG had significantly superior BLI traits in XNSN dairy goat. The different genotypes of SNP5-ScaII locus had significantly associated with BW, demonstrating that the genotype AA and GG was superior to AG in XNSN dairy goat. The different genotypes of SNP6-PstI locus had significant associate with $\mathrm{BL}$, which demonstrated that the genotype $\mathrm{CC}$ and $\mathrm{GG}$ was superior to $\mathrm{CG}$ in XNSN dairy goat. In SNP7-MspI locus, the different genotypes were found to be significantly associate with $\mathrm{CaC}$ and $\mathrm{CaCI}$ traits in HNBG and TI trait in XNSN dairy goat. For the locus, the genotype GG was superior in HNBG and genotype AA and AG in XNSN dairy goat.

\section{Effects of the interaction of each two single nucleotide polymorphisms to growth traits}

Though the $r^{2}$ values of HNBG between SNP6 and SNP7 were low, but at the same time, the D' values were
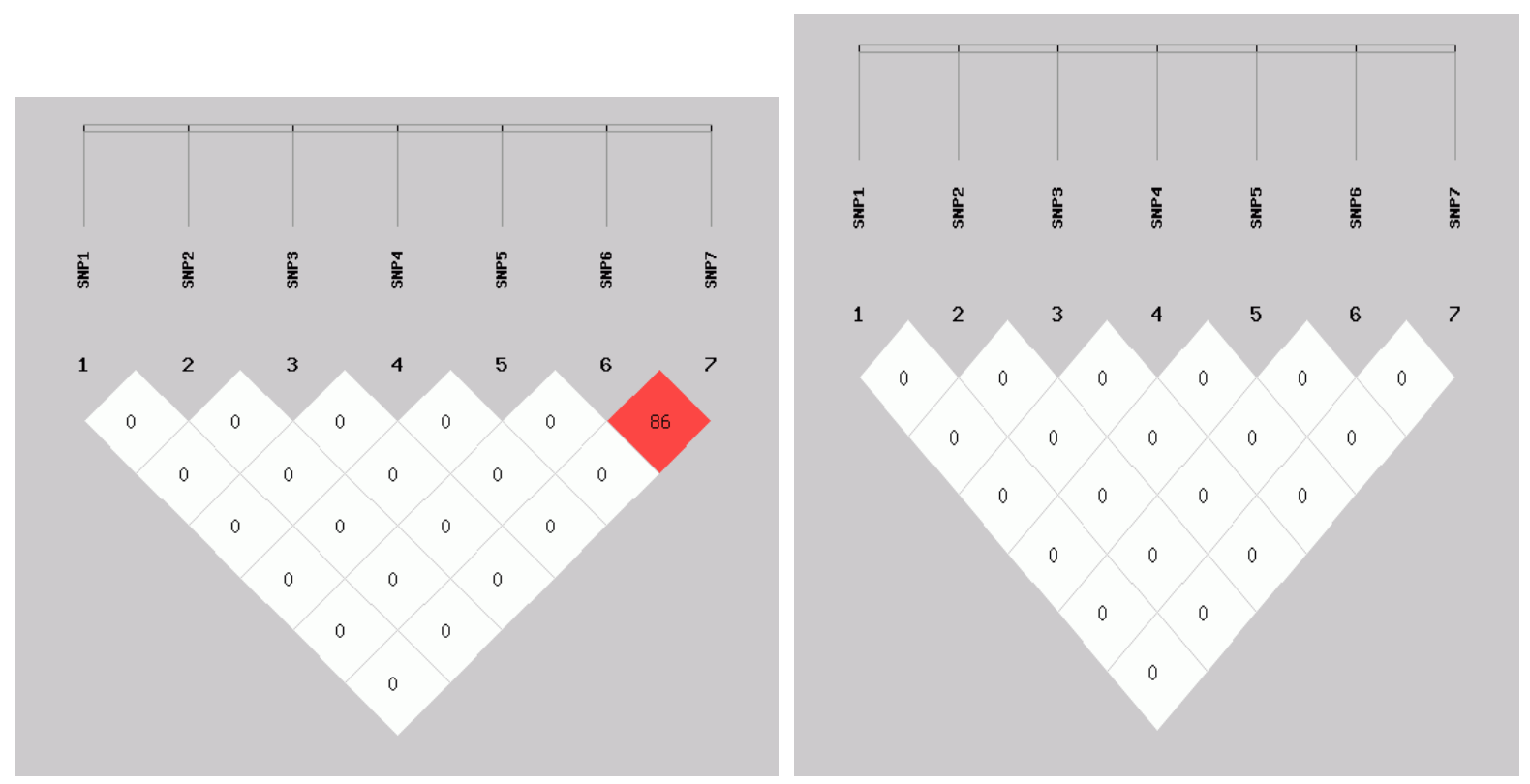

Figure 3. Linkage disequilibrium (LD) plot of $A T B F 1$ gene in HNBG. ATBF1, AT motif-binding factor 1; HNBG, Hainan Black goat. 
Table 5. $\mathrm{D}^{\prime}$ and $\mathrm{r}^{2}$ values of pairwise linkage disequilibrium of the ATBF1 gene in XNSN goat

\begin{tabular}{rccccccc}
\hline Locus/D' & SNP1 & SNP2 & SNP3 & SNP4 & SNP5 & SNP6 & SNP7 \\
\hline SNP1 & - & 0.00 & 0.00 & 0.00 & 0.00 & 0.00 & 0.00 \\
SNP2 & - & - & 0.00 & 0.026 & 0.190 & 0.073 & 0.005 \\
SNP3 & - & - & - & 0.00 & 0.00 & 0.00 & 0.00 \\
SNP4 & - & - & - & - & 0.670 & 0.574 & 0.642 \\
SNP5 & - & - & - & - & - & 0.461 & 0.306 \\
SNP6 & - & - & - & - & - & - & 0.737 \\
SNP7 & - & - & - & - & - & - & 0.00 \\
Locus/r & - & - & -00 & 0.00 & 0.00 & 0.00 & 0.00 \\
SNP1 & - & - & 0.00 & 0.00 & 0.029 & 0.002 & 0.00 \\
SNP2 & - & - & - & 0.00 & 0.00 & 0.00 & 0.00 \\
SNP3 & - & - & - & - & 0.256 & 0.086 & 0.301 \\
SNP4 & - & - & - & - & - & 0.077 & 0.081 \\
SNP5 & - & - & - & - & - & - & 0.186 \\
SNP6 & - & - & - & - & - & - \\
SNP7 & - & - & - & & & - \\
\hline
\end{tabular}

ATBF1, AT motif-binding factor 1; XNSN, Xinong Saanen dairy goat; SNP, single nucleotide polymorphism.

high (0.861), so we analyzed the effects of the interaction between SNP6 and SNP7 of HNBG with growth traits as well as between SNP4 and SNP5 (0.670), SNP4 and SNP6 (0.574), SNP4 and SNP7 (0.642), SNP6 and SNP7 (0.737) of XNSN. As shown in Table 7, the diplotypes of SNP6 and SNP7 were found to have significant effects on $\mathrm{ChC}(\mathrm{p}=$ 0.025). The phenotype $\mathrm{ChC}$ trait of combined genotypes CC-AA, CC-AG, CC-GG, CG-AG, and GG-GG was greater than $\mathrm{CG}-\mathrm{GG}$ in XNSN.

\section{DISCUSSION}

As a cancer suppressor gene, $A T B F 1$ gene not only

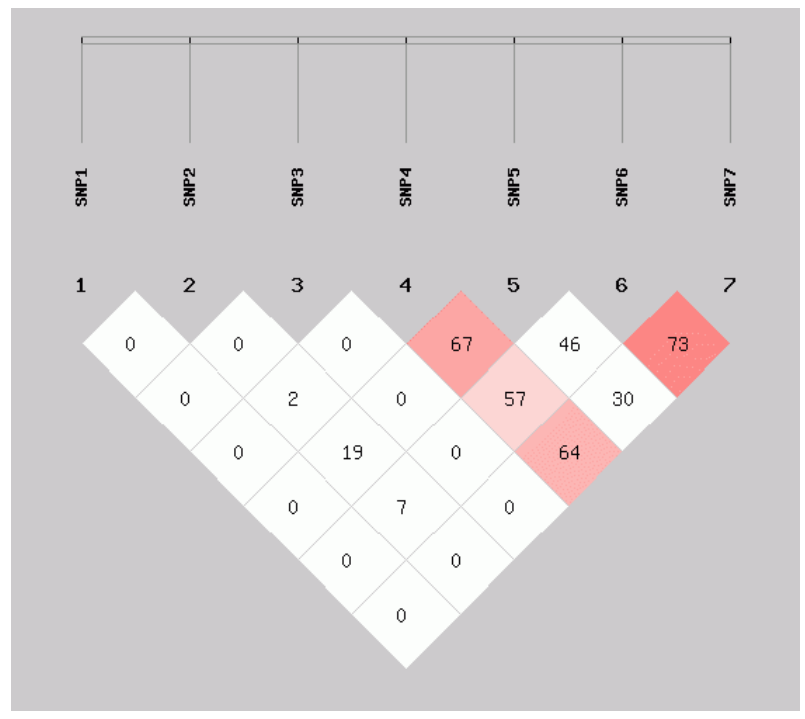

regulates cell proliferation and differentiation (Ninomiya et al., 2002; Ishii et al., 2003; Jung et al., 2011), but also interacts with PIAS3 to suppress STAT3 signaling way (Nishio et al., 2012; Jiang et al., 2014). Most importantly, ATBF1 is necessary for the Pit1 gene activation, indicating that ATBF1 could indirectly participate in the regulative roles of Pitl gene, including regulating Wnt/beta-catenin pathway and POU1F1 pathway (Carvalho et al., 2006; Qi et al., 2008; Davis et al., 2010). All these functional experiments suggested that the ATBF1 gene would affect growth traits of livestock. Therefore, this work studied the relationship between the nucleotide variations of this gene and growth related traits in goats.

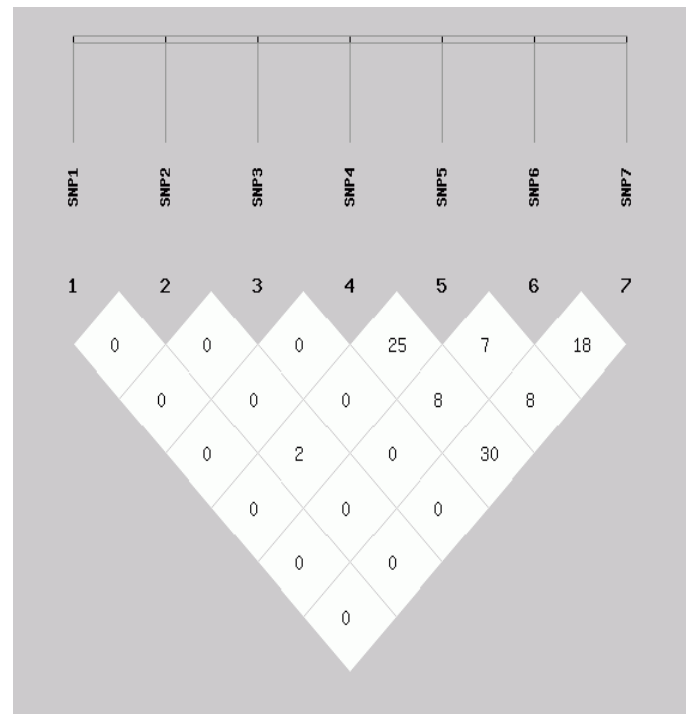

Figure 4. Linkage disequilibrium (LD) plot of $A T B F 1$ gene in XNSN. ATBF1, AT motif-binding factor 1; XNSN, Xinong Saanen dairy goat. 
Table 6. Relationship between the novel SNPs of the goat $A T B F 1$ gene and growth traits

\begin{tabular}{|c|c|c|c|c|}
\hline Locus/growth traits & \multicolumn{3}{|c|}{ Observed genotypes (LSM \pm SE) } & $\mathrm{p}$ value \\
\hline \multicolumn{5}{|l|}{ SNP2-MspI } \\
\hline XNSN breed & AA & $\mathrm{AG}$ & GG & \\
\hline $\mathrm{BL}$ & $75.21 \pm 0.79^{b}$ & $77.50 \pm 0.90^{\mathrm{ab}}$ & $77.58 \pm 0.61^{\mathrm{a}}$ & 0.039 \\
\hline $\mathrm{ChC}$ & $87.58 \pm 0.91^{\mathrm{b}}$ & $89.57 \pm 0.90^{\mathrm{ab}}$ & $90.35 \pm 0.71^{\mathrm{a}}$ & 0.045 \\
\hline BLI & $111.01 \pm 1.34^{\mathrm{b}}$ & $114.98 \pm 0.97^{\mathrm{a}}$ & $115.14 \pm 0.99^{\mathrm{a}}$ & 0.021 \\
\hline $\mathrm{ChCI}$ & $129.22 \pm 1.46^{\mathrm{b}}$ & $132.96 \pm 1.23^{\mathrm{ab}}$ & $134.12 \pm 1.23^{\mathrm{a}}$ & 0.027 \\
\hline HNBG breed & AA & $\mathrm{AG}$ & GG & \\
\hline HuWI & $109.40 \pm 1.80^{\mathrm{ab}}$ & $111.72 \pm 1.20^{\mathrm{a}}$ & $105.39 \pm 1.25^{\mathrm{b}}$ & 0.007 \\
\hline \multicolumn{5}{|l|}{ SNP5-ScaII } \\
\hline XNSN breed & AA & $\mathrm{AG}$ & GG & \\
\hline BW & $68.25 \pm 0.47^{\mathrm{a}}$ & $66.82 \pm 0.45^{b}$ & $69.33 \pm 0.59^{\mathrm{a}}$ & 0.004 \\
\hline \multicolumn{5}{|l|}{ SNP6-PstI } \\
\hline XNSN breed & $\mathrm{CC}$ & CG & GG & \\
\hline BL & $77.66 \pm 0.43^{\mathrm{a}}$ & $76.23 \pm 0.63^{b}$ & $80.65 \pm 1.42^{\mathrm{a}}$ & 0.016 \\
\hline \multicolumn{5}{|l|}{ SNP7-MspI } \\
\hline XNSN breed & AA & $\mathrm{AG}$ & GG & \\
\hline TI & $116.20 \pm 0.75^{\mathrm{a}}$ & $116.92 \pm 0.69^{\mathrm{a}}$ & $113.84 \pm 0.68^{b}$ & 0.018 \\
\hline HNBG breed & AA & $\mathrm{AG}$ & GG & \\
\hline $\mathrm{CaC}$ & $7.70 \pm 0.09^{b}$ & $7.65 \pm 0.08^{\mathrm{b}}$ & $7.96 \pm 0.07^{\mathrm{a}}$ & 0.009 \\
\hline $\mathrm{CaCI}$ & $14.59 \pm 0.19^{\mathrm{a} b}$ & $14.51 \pm 0.21^{\mathrm{b}}$ & $15.06 \pm 0.13^{\mathrm{a}}$ & 0.046 \\
\hline
\end{tabular}

SNPs, single nucleotide polymorphisms; ATBF1, AT motif-binding factor 1; LSM, lease squares means; SE, standard error; MspI, Moraxella species; XNSN, Xinong Saanen dairy goat; BL, body length; ChC, chest circumference; BLI, body length index; ChCI, chest circumference index; HNBG, Hainan Black goat; HuWI, hucklebone width index; ScaII, Streptomyces achromogenes; BW, body weight; MspI, Moraxella species; TI, trunk index; CaC, cannon circumference; $\mathrm{CaCl}$, cannon circumference index.

The values with different letters $\left({ }^{\mathrm{a}}\right.$ and ${ }^{\mathrm{b}}$ ) within the same row differ significantly at $\mathrm{p}<0.05$ and $\mathrm{p}<0.01$, respectively.

We found seven novel SNPs, of which two were missense mutations (SNP1 and SNP3), two were synonymous changes (SNP2 and SNP6) and three SNPs loci (SNP4, SNP5, and SNP7) were located at several introns. The missense mutation loci (SNP1 and SNP3) only had one kind of genotype of each locus, meaning that the mutation frequency was very low. The missense mutation with amino acid change could affect protein structure, resulting in loss of normal function, which might cause embryonic lethality. We detected haplotypes structure and found the common haplotype (hap1) had a relatively high frequency in two breeds, for the haplotype was present in the population for a long time. The haplotypes of highest frequencies in HNBG and XNSN dairy goat were different, probably caused by variety distinctiveness.

Association testing revealed that the SNP2, SNP5, SNP6 and SNP7 loci were also found to significantly associate with growth-related traits in goats. Among them, although SNP2 and SNP6 were synonymous mutations, they might affect transcriptional efficiency for codon preference and stability of mRNA (Chamary et al., 2005). Many studies have shown that no change of amino acid sequence could still affect gene performance, for example, two synonymous SNPs of bovine NUCB2 gene were significantly associated with growth traits ( $\mathrm{Li}$ et al., 2010). Although SNP5 and SNP7 were intronic mutations, they also might affect alternatively spliced transcripts of mRNA or transcription factor binding, thus affecting phenotype. A famous example of intronic mutation was located at intron 3 of the porcine $I G F 2$ gene. This mutation lead to a significant effect in skeletal muscle (Van et al., 2003). Besides, the combined genotypes of SNP6 and SNP7 in Xinong Saanen dairy goats was significantly linked to growth related traits. Therefore, this association data reflected that these nucleotide variations within $A T B F 1$ gene produced significant effects on growth related traits,

Table 7. Associations between diplotypes (combined genotypes and haplotype) of SNPs and growth traits in XNSN

\begin{tabular}{lccccccc}
\hline Growth traits & \multicolumn{5}{c}{ Diplotype loci (SNP6+SNP7) } & \multicolumn{2}{c}{$\mathrm{p}$ value } \\
\hline ChC $(\mathrm{cm})$ & CC-AA & CC-AG & CC-GG & CG-AG & CG-GG & GG-GG \\
& $(\mathrm{n}=53)$ & $(\mathrm{n}=50)$ & $(\mathrm{n}=13)$ & $(\mathrm{n}=36)$ & $(\mathrm{n}=20)$ & $(\mathrm{n}=8)$ & \\
& $89.04 \pm 0.80^{\mathrm{a}}$ & $89.96 \pm 0.74^{\mathrm{a}}$ & $91.00 \pm 1.03^{\mathrm{a}}$ & $89.94 \pm 1.05^{\mathrm{a}}$ & $85.85 \pm 1.17^{\mathrm{b}}$ & $92.62 \pm 1.51^{\mathrm{a}}$ & 0.025 \\
\hline
\end{tabular}

SNPs, single nucleotide polymorphisms; XNSN, Xinong Saanen dairy goat; ChCI, chest circumference index.

The values with different letters ( $a$ and $b$ ) within the same row differ significantly at $p<0.05$ and $p<0.01$, respectively. 
suggesting that this gene can be used as a marker gene in improving goat growth traits.

Briefly, seven novel SNPs mutations were firstly found, and four of them significantly affected goat growth related traits, which extends the known genetic variations spectrum of goat $A T B F 1$ gene and is a benefit towards implementing MAS in genetics and breeding of goats.

\section{CONFLICT OF INTEREST}

We certify that there is no conflict of interest with any financial organization regarding the material discussed in the manuscript.

\section{ACKNOWLEDGMENTS}

This work was supported by the National Natural Science Foundation of China (No.31172184), the Young New Star Project on Science \& Technology of Shaanxi Province (No.2011kjxx64) and Technology Foundation for Selected Overseas Chinese Scholar of Shaanxi Province (Xianyong Lan, 2014). We greatly thank the staff of the dairy goat breeding farm, Sanyuan country, Shaanxi province, P.R. China, the meat goat breeding farm, Zanzhou, Hainan province, P.R. China, for their collecting dairy goat samples and meat goat samples.

\section{REFERENCES}

Akcay, A., K. Ulucan, N. Taskin, M. Boyraz, T. Akcay, O. Zurita, A. Gomez, K. E. Heath, and A. Campos-Barros. 2013. Suprasellar mass mimicking a hypothalamic glioma in a patient with a complete PROP1 deletion. Eur. J. Med. Genet. 56:445-451.

Araujo, R. V., C. V. Chang, V. A. S. Cescato, M. C. B. V. Fragoso, M. D. Bronstein, B. B. Mendonca, I. J. P. Arnhold, and L. R. S. Carvalho. 2013. PROP1 overexpression in corticotrophinomas: evidence for the role of PROP1 in the maintenance of cells committed to corticotrophic differentiation. Clinics 68:887-891.

Bastos, E., S. Ávila, A. Cravador, R. Renaville, P. H Guedes, and C. J Luis. 2006. Identification and characterization of four splicing variants of ovine POU1F1 gene. Gene 382:12-19.

Benjamin, E. J., K. M. Rice, D. E. Arking, A. Pfeufer, C. van Noord, A. V. Smith, R. B. Schnabel, J. C. Bis, E. Boerwinkle, and M. F. Sinner et al. 2009. Variants in $Z F H X 3$ are associated with atrial fibrillation in individuals of European ancestry. Nat. Genet. 41:879-881.

Carvalho, L., R. D. Ward, M. L. Brinkmeier, M. A. Potok, A. H. Vesper, and S. A. Camper. 2006. Molecular basis for pituitary dysfunction: Comparison of Prop1 and Pit1 mutant mice. Dev. Biol. 295:340.

Chamary, J. V. and L. D. Hurst. 2005. Evidence for selection on synonymous mutations affecting stability of mRNA secondary structure in mammals. Genome Biol. 6:R75.

Choudhary, V., P. Kumar, T. K. Bhattacharya, B. Bhushan, A. Sharma, and A. Shukla. 2007. DNA polymorphism of insulin- like growth factor-binding protein-3 gene and its association with birth weight and body weight in cattle. J. Anim. Breed. Genet. 124:29-34.

Cleton-Jansen, A. M., R. van Eijk, M. Lombaerts, M. K. Schmidt, L. J. Van't Veer, K. Philippo, R. M. E. Zimmerman, J. L. Peterse, V. T. B. H. M. Smit, T. van Wezel, C. J. Cornelisse, A. M. Cleton-Jansen, R. Van Eijk, and M. Lombaerts. 2008. ATBF1 and NQO1 as candidate targets for allelic loss at chromosome arm 16q in breast cancer: Absence of somatic ATBF1 mutations and no role for the C609T NQO1 polymorphism. BMC Cancer 8:105.

Darnell, J. E. 1997. STATs and gene regulation. Science 277(5332):1630-1635

Davis, S. W., F. Castinetti, L. R. Carvalho, B. S. Ellsworth, M. A. Potok, R. H. Lyons, M. L. Brinkmeier, L. T. Raetzman, P. Carninci, A. H. Mortensen, Y. Hayashizaki, I. J. P. Arnhold, B. B. Mendonca, T. Brue, and S. A. Camper. 2010. Molecular mechanisms of pituitary organogenesis: In search of novel regulatory genes. Mol. Cell. Endocrinol. 323:4-19.

Fang, Q., A. M. Giordimaina, D. F. Dolan, S. A. Camper, and M. Mustapha. 2012. Genetic Background of Propl(df) mutants provides remarkable protection against hypothyroidisminduced hearing impairment. J. Assoc. Res. Otolaryngol. 13:173-184.

Fang, X. T., H. X Xu, C. L. Zhang, J. M. Zhang, X. Y. Lan, C. W. $\mathrm{Gu}$, and H. Chen. 2010. Polymorphisms in BMP-2 gene and their associations with growth traits in goats. Genes Genomics 32:29-35.

Gilbert, R. P., D. R. Bailey, and N. H. Shannon. 1993. Linear body measurements of cattle before and after twenty years of selection for post weaning gain when fed two different diets. J. Anim. Sci. 71:1712-1720.

Godi, M., S. Mellone, L. Tiradani, R. Marabese, C. Bardelli, M. Salerno, F. Prodam, S. Bellone, A. Petri, P. MomiglianoRichiardi, G. Bona, and M. Giordano. 2012. Functional SNPs within the intron 1 of the PROP1 gene contribute to combined growth hormone deficiency (CPHD). J. Clin. Endocrinol. Metab. 97:E1791-E1797.

Green, M. R. and J. Sambrook. 2012. Molecular cloning: a laboratory manual. Cold Spring Harbor Laboratory Press, New York, USA. 65-73.

Gudbjartsson, D. F., H. Holm, S. Gretarsdottir, and G. Thorleifsson, G. B. Walters, G. Thorgeirsson, J. Gulcher, E. B. Mathiesen, I. Njølstad, and A. Nyrnes et al. 2009. A sequence variant in ZFHX3 on 16q22 associates with atrial fibrillation and ischemic stroke. Nat. Genet. 41:876-878.

Guy, J. C., C. S. Hunter, A. D. Showalter, T. P. L. Smith, K. Charoonpatrapong, K. W. Sloop, J. P. Bidwell, and S. J. Rhodes. 2004. Conserved amino acid sequences confer nuclear localization upon the Prophet of Pit-1 pituitary transcription factor protein. Gene 336:263-273.

He, H., H. L. Zhang, Z. X. Li, Y. Liu, and X. L. Liu. 2014. Expression, SNV identification, linkage disequilibrium, and combined genotype association analysis of the muscle-specific gene CSRP3 in Chinese cattle. Gene 535:17-23.

Heinrich, P. C., I. Behrmann, G. Muller-Newen, F. Schaper, and L. Graeve. 1998. Interleukin-6-type cytokine signalling through the gp130/Jak/STAT pathway. Biochem. J. 334:297-314.

Ishii, Y., M. Kawaguchi, K. Takagawa, T. Oya, S. Nogami, A. 
Tamura, Y. Miura, A. Ido, N. Sakata, T. Hashimoto-Tamaoki, T. Kimura, T. Saito, T. Tamaoki, and M. Sasahara. 2003. ATBF1A protein, but not ATBF1-B, is preferentially expressed in developing rat brain. J. Comp. Neurol. 465:57-71.

Jiang, Q., B. Ni, J. Shi, Z. L. Han, R. D. Qi, W. H. Xu, D. Wang, D. W. Wang, and M. L. Chen. 2014. Down-regulation of ATBF1 activates STAT3 signaling via PIAS3 in pacing-induced HL-1 atrial myocytes. Biochem. Biophys. Res. Commun. 449:278283.

Jung, C. G., H. J. Kim, M. Kawaguchi, K. K. Khanna, H. Hida, K. Asai, H. Nishino, and Y. Miura. 2005. Homeotic factor ATBF1 induces the cell cycle arrest associated with neuronal differentiation. Development 132:5137-5145.

Jung, C. G., K. O. Uhm, Y. Miura, T. Hosono, H. Horike, K. K. Khanna, M. J. Kim, and M. Michikawa. 2011. Beta-amyloid increases the expression level of ATBF1 responsible for death in cultured cortical neurons. Mol. Neurodegener. 6:47.

Kai, K., Z. Zhang, H. Yamashita, Y. Yamamoto, Y. Miura, and H. Iwase. 2008. Loss of heterozygosity at the ATBF1-A locus located in the $16 \mathrm{q} 22$ minimal region in breast cancer. BMC Cancer 8:262.

Kamohara, Y., N. Sugiyama, T. Mizuguchi, D. Inderbitzin, H. Lilja, Y. Middleton, T. Neuman, A. A. Demetriou, and J. Rozga. 2000. Inhibition of signal transducer and activator transcription factor 3 in rats with acute hepatic failure. Biochem. Biophys. Res. Commun. 273:129-135.

Lan, X. Y., C. Y. Pan, H. Chen, C. L. Zhang, J. Y. Li, M. Zhao, C. Z. Lei, A. L. Zhang, and L. Zhang. 2007. An AluI PCR-RFLP detecting a silent allele at the goat POUIF1 locus and its association with production traits. Small Rumin. Res. 73:8-12.

Lan, X. Y., H. Y. Zhao, Z. J. Li, R. Zhou, C. Y. Pan, C. Z. Lei, and H. Chen. 2013. Exploring the novel genetic variant of PITXI gene and its effect on milk performance in dairy goats. J. Integr. Agric. 12:118-126.

Li, M., X. Fu, G. Ma, X. D. Sun, X. Y. Dong, T. Nagy, C. S. Xing, J. Li, and J. T. Dong. 2012. Atbf1 regulates pubertal mammary gland development likely by inhibiting the pro-proliferative function of estrogen-ER signaling. PLoS One 7(12):e51283.

Li, M., D. Zhao, G. Ma, B. Zhang, X. Fu, Z. Zhu, L. Fu, X. Sun, and J. T. Dong. 2013. Upregulation of ATBF1 by progesteronePR signaling and its functional implication in mammary epithelial cells. Biochem. Biophys. Res. Commun. 430:358363.

Li, F., H. Chen, C. Z. Lei, G. Ren, J. Wang, Z. J. Li, and J. Q. Wang. 2010. Novel SNPs of the bovine NUCB2 gene and their association with growth traits in three native Chinese cattle breeds. Mol. Biol. Rep. 37:541-546.

Li, Z. Q., Z. Zhang, Z. He, W. Tang, T. Li, Z. Zeng, L. He, and Y. Y. Shi. 2009. A partition-ligation-combination-subdivision EM algorithm for haplotype inference with multiallelic markers: update of the SHEsis. Cell Res. 19:519-523.

Massagué, J. 2012. TGF- $\beta$ signalling in context. Nat. Rev. Mol. Cell Biol. 13:616-630.

Massagué, J., J. Seoane, and D. Wotton. 2005. Smad transcription factors. Genes Dev. 19:2783-2810.

Morinaga, T., H. Yasuda, T. Hashimoto, K. Higashio, and T. Tamaoki. 1991. A human alpha-fetoprotein enhancer-binding protein, ATBF1, contains four homeodomains and seventeen zinc fingers. Mol. Cell. Biol. 11:6041-6049.
Moustakas, A. and C. H. Heldin. 2009. The regulation of TGF- $\beta$ signal transduction. Development 136:3699-3714.

Navardauskaite, R., P. Dusatkova, B. Obermannova, R. W. Pfaeffle, W. F. Blum, D. Adukauskiene, N. Smetanina, O. Cinek, R. Verkauskiene, and J. Lebl. 2014. High prevalence of PROP1 defects in Lithuania: Phenotypic findings in an ethnically homogenous cohort of patients with multiple pituitary hormone deficiency. J. Clin. Endocrinol. Metab. 99:299-306.

Ninomiya, T., K. Mihara, K. Fushimi, Y. Hayashi, T. HashimotoTamaoki, and T. Tamaoki. 2002. Regulation of the alphafetoprotein gene by the isoforms of ATBF1 transcription factor in human hepatoma. Hepatology 35:82-87.

Nishio, E., Y. Miura, M. Kawaguchi, and A. Morita. 2012. Nuclear translocation of ATBF1 is a potential prognostic marker for skin cancer. Acta Dermatovenerol. Croat. 20:239-245.

Nojiri, S., T. Joh, Y. Miura, N. Sakata, T. Nomura, H. Nakao, S. Sobue, H. Oharra, K. Asai, and M. Ito. 2004. ATBF1 enhances the suppression of STAT3 signaling by interaction with PIAS3. Biochem. Biophys. Res. Commun. 314:97-103.

Pan, C. Y., C. Y. Wu, W. C. Jia, Y. Xu, C. Z. Lei, S. R. Hu, X. Y. Lan, and H. Chen. 2013. A critical functional missense mutation (H173R) in the bovine PROP1 gene significantly affects growth traits in cattle. Gene 531:398-402.

Perea, D., K. Molohon, K. Edwards, and F. J. Diaz-Benjumea. 2013. Multiple roles of the gene zinc finger homeodomain-2 in the development of the Drosophila wing. Mech. Dev. 130: 467-481.

Qi, Y. C., J. A. Ranish, X. Y. Zhu, A. Krones, J. Zhang, R. Aebersold, D. W. Rose, M. G. Rosenfeld, and C. Carriere. 2008. Atbf1 is required for the Pit 1 gene early activation. Proc. Natl. Acad. Sci. USA 105:2481-2486.

Sakata, N., S. Kaneko, S. Ikeno, Y. Miura, H. Nakabayashi, X. Y. Dong, J. T. Dong, T. Tamaoki, N. Nakano, and S. Itoh. 2014. TGF- $\beta$ Signaling Cooperates with AT Motif-Binding Factor-1 for Repression of the $\alpha$-Fetoprotein Promoter. J. Signal Transduct. Article ID 970346.

Sambrock, J. and D. W. Russell. 2001. Molecular Cloning: A Laboratory Manual. Cold Spring Harbor Laboratory Press, NY, USA.

Schindler, C. and J. E. Darnell. 1995. Transcriptional responses to polypeptide ligands: The JAK-STAT pathway. Annu. Rev. Biochem. 64:621-652.

Shuai, K. 1999. The STAT family of proteins in cytokine signaling. Prog. Biophys. Mol. Biol. 71:405-422.

Sun, X., X. Fu, J. Li, C. S. Xing, D. W. Martin, H. H. Zhang, Z. J. Chen, and J. T. Dong. 2012. Heterozygous deletion of Atbfl by the Cre-loxP system in mice causes preweaning mortality. Genesis 50:819-827.

Sun, X. D., X. Y. Fu, J. Li, C. S. Xing, H. F. Frierson, H. Wu, X. K. Ding, T. Z. Ju, R. D. Cummings, and J. T. Dong. 2014. Deletion of Atbf1/Zfhx3 in mouse prostate causes neoplastic lesions, likely by attenuation of membrane and secretory proteins and multiple signaling pathways. Neoplasia 16:377389.

Sun, X. D., Y. F. Zhou, K. B. Otto, M. R. Wang, C. S. Chen, W. Zhou, K. Subramanian, P. M. Vertino, and J. T. Dong. 2007. Infrequent mutation of ATBF1 in human breast cancer. J. Cancer Res. Clin. 133:103-105.

Van Laere, A. S., M. Nguyen, M. Braunschweig, C. Nezer, C. 
Collette, L. Moreau, A. L. Archibald, C. S. Haley, N. Buys, and M. Tally et al. 2003. A regulatory mutation in $I G F 2$ causes a major QTL effect on muscle growth in the pig. Nature 425 : 832-836.

Wang, A. L., Y. Zhang, M. J. Li, X. Y. Lan, J. Q. Wang, and H. Chen. 2013. SNP identification in FBXO32 gene and their associations with growth traits in cattle. Gene 515:181-186.

Wang, G., S. Zhang, S. Wei, Y. Zhang, Y. Li, C. Fu, C. Zhao, and L. Zan. 2014. Novel polymorphisms of SIX4 gene and their association with body measurement traits in Qinchuan cattle. Gene 539:107-110.

Yasuda, H., A. Mizuno, T. Tamaoki, and T. Morinaga. 1994. ATBF1, a multiple-homeodomain zinc finger protein, selectively down-regulates AT-rich elements of the human $\alpha$ fetoprotein gene. Mol. Cell. Biol. 14:1395-1401.
Yeh, F. C., R. Yang, T. J. Boyle, Z. Ye, and J. M. Xiyan. 2000. PopGene32, Microsoft Windows-based freeware for population genetic analysis, version 1.32. Molecular Biology and Biotechnology Centre, University of Alberta, Edmonton, $\mathrm{AB}$, Canada.

Zhao, H. Y., X. F. Wu, H. F. Cai, C. Y. Pan, C. Z. Lei, H. Chen, X. Y. Lan. 2013. Genetic variants and effects on milk traits of the caprine paired-like homeodomain transcription factor 2 (PITX2) gene in dairy goats. Gene 532:203-210.

Zhong, Z., Z. L. Wen, and J. E. Darnell. 1994. Stat3: A STAT family member activated by tyrosine phosphorylation in response to epidermal growth factor and interleukin-6. Science 264(5155):95-98. 